\title{
Genetic support for the morphological identification of larvae of Myctophidae, Gonostomatidae, Sternoptychidae and Phosichthyidae (Pisces) from the western Mediterranean
}

\author{
Ainhoa Bernal ${ }^{1}$, Jordi Viñas ${ }^{2}$, M. Pilar Olivar ${ }^{1}$ \\ ${ }^{1}$ Institut de Ciències del Mar (CSIC), Passeig Marítim de la Barceloneta 37-49, 08003 Barcelona, Spain. \\ E-mail: bernal@icm.csic.es \\ ${ }^{2}$ Laboratori d'Ictiologia Genètica, Facultat de Ciències, Universitat de Girona, Maria Aurèlia Capmany 69, 17071 Girona, \\ Spain.
}

\begin{abstract}
Summary: Mesopelagic fishes experience an extreme body transformation from larvae to adults. The identification of the larval stages of fishes from the two orders Myctophiformes and Stomiiformes is currently based on the comparison of morphological, pigmentary and meristic characteristics of different developmental stages. However, no molecular evidence to confirm the identity of the larvae of these mesopelagic species is available so far. Since DNA barcoding emerged as an accurate procedure for species discrimination and larval identification, we have used the cytochrome c oxidase 1 or the mitochondrial $12 \mathrm{~S}$ ribosomal DNA regions to identify larvae and adults of the most frequent and abundant species of myctophiforms (family Myctophidae) and stomiiforms (families Gonostomatidae, Sternoptychidae and Phosichthyidae) from the Mediterranean Sea. The comparisons of sequences from larval and adult stages corroborated the value of the morphological characters that were used for taxonomic classification. The combination of the sequences obtained in this study and those of related species from GenBank was used to discuss the consistency of monophyletic clades for different genera. Pairwise nucleotide distances were notably higher inter- than intraspecifically, and were useful to discern between congeners such as Cyclothone braueri and C. pygmaea, Hygophum benoiti and H. hygomii, Lampanyctus crocodilus and L. pusillus, and Notoscopelus bolini and N. elongatus.
\end{abstract}

Keywords: barcoding; CO1; 12S rRNA; larval identification; western Mediterranean Sea; mesopelagic fish.

Apoyo genético para la identificación morfológica de las larvas de Myctophidae, Gonostomatidae, Sternoptychidae y Phosichthyidae (Pisces) del Mediterráneo Occidental

Resumen: Los peces mesopelágicos experimentan una transformación radical desde las fases larvarias hasta que alcanzan el estado adulto. La identificación de las fases larvarias de peces procedentes de los órdenes Myctophiformes y Stomiiformes se basa actualmente en la comparación de caracteres morfológicos, de pigmentación y merísticos entre diferentes estados de desarrollo. El objetivo de este estudio consistió en demostrar la existencia de evidencias genéticas que confirmen la identificación correcta de las larvas de estas especies de peces mesopelágicos en base a la clásica clasificación morfológica. Las regiones de ADN mitocondrial correspondientes al gen citocromo oxidasa 1, o alternativamente, el gen que codifica la subunidad 12 S del rARN, fueron secuenciadas parcialmente, tras lo cual se aplicó el procedimiento "DNA barcoding" para la identificación de larvas y adultos de las especies más abundantes y frecuentes de Myctophiformes (Familia Myctophidae) y Stomiiformes (Familia Gonostomatidae, Sternoptichydae y Phosychthiydae) del Mediterráneo. Las comparaciones por pares de las secuencias de larvas y adultos corroboraron el valor de los caracteres morfológicos utilizados en las clasificaciones taxonómicas. Dichas secuencias en combinación con otras secuencias de las mismas especies, o géneros, obtenidas a partir de GenkBank, permitieron discutir la solidez de grupos monofiléticos para diversos géneros. Las distancias nucleotídicas entre pares de secuencias fueron considerablemente superiores a nivel interespecífico que intraspecífico, y permitieron discernir entre congéneres tales como Cyclothone braueri y C. pygmaea, Hygophum benoiti e H. hygomii, Lampanyctus crocodilus y L. pusillus, y Notoscopelus bolini y N. elongatus.

Palabras clave: barcoding; citocromo oxidasa 1 (CO1); 12S rARN; identificación de larvas; Mediterráneo Occidental; peces mesopelágicos.

Citation/Como citar este artículo: Bernal A., Viñas J., Olivar M.P. 2014. Genetic support for the morphological identification of larvae of Myctophidae, Gonostomatidae, Sternoptychidae and Phosichthyidae (Pisces) from the western Mediterranean. Sci. Mar. 78(4): 461-471. doi: http://dx.doi.org/10.3989/scimar.04072.27A

Editor: M. Pascual.

Received: April 3, 2014. Accepted: September 10, 2014. Published: October 27, 2014.

Copyright: (C) 2014 CSIC. This is an open-access article distributed under the Creative Commons Attribution-Non Commercial Lisence (by-nc) Spain 3.0. 


\section{INTRODUCTION}

Ecological interactions of fish assemblages in the pelagic environment can be partially determined by their larval distributions and recruitment to adult populations. The identification of early life stages, such as larvae and transforming young, is essential for current studies on the distribution and reproductive strategies of pelagic fishes (Takeyama et al. 2001, Moura et al. 2008, Valdez-Moreno et al. 2010). Thus, the assessment of biodiversity and its implication in the management of vulnerable marine ecosystems requires an accurate taxonomic assignment of fish larvae. Without this knowledge, the abundance of cryptic or unknown species might be under- or overestimated.

The identification of fish larvae has been an important morphological issue in marine ecology due to the dramatic transformations that most species undergo from early larval stages to adulthood (Burton 1996). Some ambiguity also arises when attempting to identify larval stages of closely related species with slight morphological and pigmentation differences (Blaxter 1984). Recently, a few studies on pelagic fishes have used molecular markers to determine unidentified larvae or those larvae suspected of misidentification (e.g. Takeyama et al. 2001, Kochzius et al. 2010, Ko et al. 2013) due to errors in the fishes' morphological identification. One such study showed that various fishes assigned to three families with widely differing morphologies were actually male, female and larvae of a single family (Johnson et al. 2009).

The effective discrimination of species through mitochondrial DNA (mtDNA) analyses has been stated in earlier fish studies (e.g. Hare et al. 1994, Takeyama et al. 2001, Viñas and Tudela 2009). An international interest in fisheries sparked a launch of the "Barcode of Life Project (iBOL)" (Hebert et al. 2003), which determined that mtDNA cytochrome c oxidase 1 (CO1) was a suitable gene marker for fish species identification due to the fast evolution of the mtDNA, its maternal inheritance and haploid condition (Moore 1995). Sequencing this gene allows the amplification of large and low-variable sequences (Hebert et al. 2004, Steinke et al. 2009). Hebert et al. (2004) suggested a 10Xthreshold of intraspecific genetic divergence, known as the barcoding gap, to discriminate at species level. This threshold establishes a quantifiable limit between intra- and interspecific variability, and determines when the DNA sequences share a monophyletic origin. Miya and Nishida (2000) reported the validity of CO1 within a group of protein-coding genes as appropriate markers for the recovery of the expected phylogeny of teleosteans. In general, species identification applies the Forensically Informative Nucleotide Sequencing (FINS) methodology, which involves the establishment of a robust phylogeny followed by a subsequent species identification of query individuals based on that previous phylogeny (Bartlett and Davidson 1992).

Originally, barcoding was only applied to fish species of commercial interest that were often mislabeled. Less focus has been placed on species with non-commercial value, such as mesopelagic fishes. These fishes are mostly included within the orders Myctophiformes and Stomiiformes, documented among the most common and abundant vertebrates in the world (Gjøsaeter and Kawaguchi 1980). Both orders include relatively small, deep-water species with distinct luminous organs (photophores), commonly known as lanternfishes and lightfishes. The location of groups of photophores, the osteological characteristics and the number of gill rakers are features typically used for species identification and for constructing their evolutionary history (Paxton 1972, Hulley 1981, Fink 1985). These features are less developed during the larval stages, leaving body shape and pigmentation patterns as the best descriptors (Jespersen and Tåning 1926, Moser et al. 1984, Olivar et al. 1999). The morphotype and conspicuous specializations of myctophiform (e.g. Moser and Ahlstrom 1974, Olivar et al. 1999) and stomiiform (e.g. Jespersen and Tåning 1926, Ahlstrom 1974, Richards 2006) larval stages are highly diverse and used in the systematics of genera and subfamilies (Moser and Ahlstrom 1974, Moser et al. 1984). For example, eye morphology in myctophid larvae discerns the two existing subfamilies Lampanyctinae (round eyes) and Myctophinae (narrow eyes) (Moser and Ahlstrom 1974).

In the Mediterranean Sea, the number of myctophiform and stomiiform species (Goodyear et al. 1972, Olivar et al. 2012) is lower than in the Atlantic, Pacific or Indian Oceans (Nafpaktitis et al. 1977, Badcock 1984, Hulley 1984). Compared with the adjacent northeastern Atlantic, the western Mediterranean only harbours 17 of the 57 myctophid, 3 of the 17 gonostomatid, 2 of the 11 sternoptychid, and 3 of the 6 phosichthyid species (Badcock 1984, Hulley 1984). Furthermore, some of the Mediterranean species, such as Notoscopelus elongatus (Costa, 1844) and Cyclothone pygmaea Jespersen and Tåning, 1926, are endemic. The larvae of all these mesopelagic fishes are well known based on descriptions of specimens collected in the Mediterranean region (Tåning 1918, Jespersen and Tåning 1926) (Supplementary Material, Table S1).

The use of genetic markers for larval identification of myctophiforms and stomiiforms has so far been limited to the larvae of the Hygophum spp. (Myctophidae) (e. g. Yamaguchi et al. 2000). The genetic evidence for constructing the evolutionary history of lanternfishes and lightfishes that inhabit the Mediterranean Sea is lacking. Phylogenetic relationships within Myctophidae had been unresolved by genetic methods until a recent study by Poulsen et al. (2013) combined sequencing of mitogenomes, coding and non-coding regions, and gene order rearrangement. The results of their study supported the classical morphological phylogeny recognized for myctophids (Paxton 1972, Paxton et al. 1984).

The objective of the present work is to assess the validity of morphological larval identifications using two mitochondrial markers, $\mathrm{CO} 1$ or $12 \mathrm{~S}$ rRNA, to accurately associate larvae and adults of the same species for the most abundant and frequent mesopelagic fishes of the western Mediterranean. Additionally, it was of interest to determine the similarity of congeneric taxa and infer the most external relationships under the resolution threshold of one mtDNA marker. 
New sequences were uploaded to GenBank, of which sequences of seven species were included for the first time (Supplementary Material, Table S2).

\section{MATERIALS AND METHODS}

\section{Sample collection}

Genetic analyses were conducted on the larvae and adults of 18 species, across 14 genera, of mesopelagic fishes. The adult collection consisted of the most abundant and frequent mesopelagic fishes in the region, of the orders Myctophiformes and Stomiiformes. For myctophiforms, 7 of 9 species of the subfamily Lampanyctinae and all species from Myctophinae (6) known to be present in the western Mediterranean were analysed (Table 1 and Supplementary Material, Table S1). Stomiiforms included Argyropelecus hemigymnus (Cocco, 1829) and Maurolicus muelleri (Gmelin, 1789) (family Sternoptychidae), Cyclothone braueri (Jespersen and Tåning, 1926) and C. pygmaea (family Gonostomatidae), and Vinciguerria attenuata (Cocco, 1838) (family Phosichthyidae).

Samples were collected on board the vessel R/V Sarmiento de Gamboa during July 2010, offshore of the Balearic Islands $\left(39^{\circ} \mathrm{N}, 2^{\circ} \mathrm{E}\right)$. Sampling procedures are described elsewhere (Olivar et al. 2012). The specimens used in this study were identified on board and preserved in $96 \%$ ethanol prior to genetic analyses. In addition, the larvae of 12 species were sorted on board. The larvae of A. hemigymnus and Notoscopelus spp., which were not available in July 2010, where taken from a preceding cruise (December 2009, IDEADOS project) in the same area, and were stored in 5\% formalin for less than one year. Adult myctophids were identified following the descriptions of Hulley (1984), while those of Jespersen and Tåning (1926) and Badcock (1984) were used to identify the stomiiforms. The larvae chosen for DNA analyses were identified on board by the third author on the basis of detailed descriptions provided in the literature listed in Supplementary Material, Table S1. Their main distinctive characters are cited in Supplementary Material, Table S3. Photographs of each ethanol-preserved larva were taken prior to DNA extraction to ensure that they were identical to the voucher specimens in the ichthyoplankton collection of the Institute of Marine Sciences (Spain).

\section{DNA barcoding}

The DNA extraction was accomplished for adults by obtaining a portion of excised musculature, while the whole body was used for larvae. The DNA was isolated from $250 \mathrm{mg}$ of tissue using the commercial kit Real Pure Spin (Durviz, Valencia, Spain) according to the manufacturer's instructions. The DNA was resuspended in $100 \mu \mathrm{l}$ of deionized water. When larval specimens stored in ethanol were not available, we at-

Table 1. - List of the genetic markers used to identify each species, stage of development, body size range, number of sequenced individuals, total number of individuals of each species in the sampling collection, and sampling location and depth. Abbreviations: No, number, NL/SL, notochord length/standard length; L, larva; T, transforming; A, adult. *The sequences of $S$. veranyi larvae showed high nucleotide variation. They constituted an isolated cluster, far apart from other myctophids and stomiiforms. For this reason they were not included for evolutionary methods.

\begin{tabular}{|c|c|c|c|c|c|c|c|}
\hline Species & $\begin{array}{l}\text { Genetic } \\
\text { marker }\end{array}$ & $\begin{array}{c}\text { Stage } \\
(\mathrm{NL} / \mathrm{SL}, \mathrm{mm})\end{array}$ & $\begin{array}{c}\text { No. of } \\
\text { sequenced } \\
\text { individuals }\end{array}$ & $\begin{array}{l}\text { No. of L in } \\
\text { collection }\end{array}$ & $\begin{array}{l}\text { Depth, } \\
\text { m }\end{array}$ & $\begin{array}{c}\text { Longitude range, } \\
{ }^{\circ} \mathrm{E}\end{array}$ & $\begin{array}{c}\text { Latitude range, } \\
{ }^{\circ} \mathrm{N}\end{array}$ \\
\hline Argyropelecus hemigymnus & $\mathrm{CO} 1$ & A $(26-28)$ & 1 & & $909-925$ & $2.15-2.41$ & $39.01-39.80$ \\
\hline Argyropelecus hemigymnus & $\mathrm{CO} 1$ & $\mathrm{~L}$ & 0 & 407 & $150-245$ & $2.22-2.70$ & $39.09-39.67$ \\
\hline Benthosema glaciale & $\mathrm{CO} 1$ & A (28) & 3 & & $909-988$ & $2.14-2.41$ & $39.01-39.82$ \\
\hline Benthosema glaciale & $\mathrm{CO} 1$ & $\mathrm{~L}(9.5-19.9)$ & 2 & 589 & $216-587$ & $2.06-2.18$ & 39.65 \\
\hline Ceratoscopelus maderensis & $\mathrm{CO} 1$ & $\mathrm{~A}(52-54)$ & 3 & & $958-970$ & $2.11-2.18$ & 39.82 \\
\hline Ceratoscopelus maderensis & $\mathrm{CO} 1$ & $\mathrm{~L}(5.1-11.4)$ & 4 & 1792 & $156-264$ & $2.69-2.72$ & $39.04-39.05$ \\
\hline Diaphus holti & $\mathrm{CO} 1$ & $\mathrm{~A}(38-44)$ & 3 & & 422 & 2.17 & 39.70 \\
\hline Diaphus holti & $\mathrm{CO} 1$ & $\mathrm{~L}(7.2)$ & 1 & 21 & 641 & 2.08 & 39.69 \\
\hline Electrona risso & $\mathrm{CO} 1$ & $\mathrm{~T}(10.5)$ & 1 & & 245 & 2.70 & 39.09 \\
\hline Hygophum benoiti & $\mathrm{CO} 1$ & $\mathrm{~A}(41-43)$ & 3 & & $909-977$ & $2.11-2.41$ & $39.01-39.82$ \\
\hline Hygophum benoiti & $\mathrm{CO} 1$ & $\mathrm{~L}(8.7-12.9)$ & 3 & 4834 & $230-938$ & $2.15-270$ & $39.07-39.81$ \\
\hline Hygophum hygomii & $\mathrm{CO} 1$ & $\mathrm{~A}(47)$ & 3 & & $958-968$ & $2.11-2.15$ & $39.81-39.82$ \\
\hline Hygophum hygomii & $\mathrm{CO} 1$ & L & 0 & 106 & $150-914$ & $2.09-2.72$ & $38.99-39.76$ \\
\hline Lampanyctus crocodilus & $\mathrm{CO} 1$ & A (69) & 2 & & $603-988$ & $2.07-2.14$ & $39.67-39.82$ \\
\hline Lampanyctus crocodilus & $\mathrm{CO} 1$ & $\mathrm{~L}(5.4-12.2)$ & 2 & 443 & $245-300$ & $2.18-2.28$ & $39.65-39.80$ \\
\hline Lampanyctus pusillus & $\mathrm{CO} 1$ & $\mathrm{~A}(36)$ & 2 & & $626-980$ & $2.07-2.14$ & $39.67-39.82$ \\
\hline Lampanyctus pusillus & $\mathrm{CO} 1$ & $\mathrm{~L}(5.3-6.0)$ & 3 & 218 & $225-248$ & $2.23-2.70$ & $39.03-39.70$ \\
\hline Lobianchia dofleini & $\mathrm{CO} 1$ & $\mathrm{~A}(37.0-37.4)$ & 3 & & $940-958$ & $2.11-2.15$ & $39.80-39.82$ \\
\hline Lobianchia dofleini & $\mathrm{CO} 1$ & $\mathrm{~L}(6.0-7-2)$ & 2 & 63 & $225-340$ & $2.21-2.28$ & $39.68-39.72$ \\
\hline Maurolicus muelleri & $\mathrm{CO} 1$ & $\mathrm{~A}(31-45)$ & 3 & & $226-422$ & $2.16-2.18$ & $39.64-39.70$ \\
\hline Maurolicus muelleri & $\mathrm{CO} 1$ & $\mathrm{~L}(9.5-10)$ & 3 & 129 & $225-245$ & $2.22-2.70$ & $39.07-39.70$ \\
\hline Myctophum punctatum & $\mathrm{CO} 1$ & $\mathrm{~A}(29-39)$ & 3 & & $156-988$ & $2.11-2.73$ & $39.07-39.82$ \\
\hline Myctophum punctatum & $\mathrm{CO} 1$ & $\mathrm{~L}(9.9-13.9)$ & 3 & 127 & $274-814$ & $2.49-2.69$ & $39.06-39.08$ \\
\hline Notoscopelus bolini & $\mathrm{CO} 1$ & $\mathrm{~A}(90)$ & 1 & & 235 & 2.28 & 39.71 \\
\hline Notoscopelus elongatus & $\mathrm{CO} 1$ & $\mathrm{~A}(41-42)$ & 2 & & $226-245$ & $2.18-2.70$ & $39.09-39.65$ \\
\hline Symbolophorus veranyi & $\mathrm{CO} 1$ & $\mathrm{~A}(56)$ & 2 & & $958-977$ & $2.11-2.15$ & $39.81-39.82$ \\
\hline Symbolophorus veranyi & $\mathrm{CO} 1$ & $\mathrm{~L}(4.08-9.0 *)$ & $3 *$ & 199 & $222-248$ & $2.18-2.70$ & $39.03-39.68$ \\
\hline Vinciguerria attenuata & $\mathrm{CO} 1$ & $\mathrm{~T}, \mathrm{~A}(12-37)$ & 7 & & $891-988$ & $2.11-2.46$ & $38.94-39.84$ \\
\hline Cyclothone braueri & $12 \mathrm{~S}$ & $A(15)$ & 1 & & $305-935$ & $2.15-2.70$ & $39.02-39.81$ \\
\hline Cyclothone braueri & $12 \mathrm{~S}$ & $\mathrm{~L}(7-7.7)$ & 3 & 3164 & $222-245$ & $2.18-2.71$ & $39.03-39.65$ \\
\hline Cyclothone pygmaea & $12 \mathrm{~S}$ & $\mathrm{~A}(21-23)$ & 2 & & $900-938$ & $2.15-2.43$ & $38.98-39.81$ \\
\hline Cyclothone pygmaea & $12 \mathrm{~S}$ & $\mathrm{~L}(4.5-5.5)$ & 0 & 68 & 893 & 2.45 & 39.01 \\
\hline
\end{tabular}


tempted to isolate the DNA from samples of larvae preserved in 5\% buffered formalin using the Chelex and Phenol/Chloroform protocols. Unfortunately, these applications were not successful.

Species identification was achieved using one of two different markers for mtDNA: cytochrome c oxidase 1 or $12 \mathrm{~S}$ ribosomal RNA (mtDNA $12 \mathrm{~S}$ rRNA). The amplification of mtDNA CO1 fragments was performed using FishF1 (5'TCAACCAACCACAAAGACATTGGCAC3') and FishR1 (5'TAGACTTCTGGGTGGCCAAAGAATCA3'), a combination of primers previously described by Ward et al. (2005). The pair FishF1/R1 was selected because of previous recommendations (Pegg et al. 2006), relying on the production of the longest and clearest amplicons that could be obtained for most species. Minimum within-species variation was expected for the $\mathrm{CO} 1$ sequences. Alternatively, for the samples that failed to amplify with this pair, two new sets of primers, LCO1Myc1/LCO1Myc2 (5'CTTCGGTGCCTGAGCCGGCATAG3', 5'CCGCCGGCGGGGTCGAAGAA3') and L-Cyc_CO1/R-Cyc_CO1 (5'ATGGTCGGCACAGCCTTA3', 5'AGGGTCGAAAAAGGAGGTGT3') were designed using Primer 3 (Rozen and Skaletsky 2000) in order to yield more optimized sets. To design these primer sets, an alignment of the sequences was performed using the primers reported in Ward et al. (2005). A fragment of at least 18 nucleotides, with the lowest possible variability among the sequences, was selected from the alignment. The 18-nucleotide fragment was input in Primer 3 to get an amplification length of at least 600 nucleotides.

The CO1 amplification, using the cited sets of primers, failed with most of the stomiiform specimens from C. braueri and C. pygmaea. Therefore, the mtDNA $12 \mathrm{~S}$ rRNA region was selected for these species. DNA fragments were amplified using the primer combination L1085/L1478 (5'TAAACCAGGATTAGATACCC3'; 5'GAGAGTGACGGGCGATGTGT3'), previously described by Miya and Nishida (2000).

The polymerase chain reactions (PCRs) were performed in $25-\mu \mathrm{l}$ or $12.5-\mu \mathrm{l}$ reaction volumes using approximately $50 \mathrm{ng}(0.5 \mu \mathrm{l})$ of the isolated DNA as a template. Each PCR contained 1X Taq DNA polymerase buffer, $1.5-2 \mathrm{mM}$ of $\mathrm{MgCl}_{2}, 200 \mathrm{mM}$ of each dNTP, 10 pMols of each primer, and $0.5 \mathrm{U}$ of Taq DNA polymerase: Amplitaq DNA polymerase (Applied Biosystems, Foster City, CA, USA) or Taq DNA polymerase (Invitrogen, Carlsbad, CA, USA).

Negative controls were included in all of the PCR runs to ensure against cross-contamination. Thermal cycles involved an initial denaturation at $95^{\circ} \mathrm{C}$ for 5 min, followed by 30 cycles of denaturing at $95^{\circ} \mathrm{C}$ for $30 \mathrm{~s}$, annealing at $50^{\circ} \mathrm{C}$ for $45 \mathrm{~s}$ and primer extension at $72^{\circ} \mathrm{C}$ for $1 \mathrm{~min}$.

PCR products were purified using $0.6 \mathrm{U}$ of Exonuclease I (Fermentas, Sankt Leon-Rot, Germany) and 0.3 U of Shrimp Alkaline phosphatase (Fermentas) at $37^{\circ} \mathrm{C}$ for $1 \mathrm{~h}$, followed by an inactivation step at $85^{\circ} \mathrm{C}$ for $15 \mathrm{~min}$. The nucleotide sequences of the PCR products were then cycle-sequenced using the BigDye terminator Cycle Sequencing kit 3.0 (Applied Biosys- tems) with the forward and reverse primers used for amplification, according to the manufacturer's recommendations. Sequences were read using an ABI Prism 310 Genetic Analyzer (Applied Biosystems).

\section{Sequence editing and analysis}

Sequence alignments were edited using BioEdit 7.0.9.0 (Hall 1999), and aligned using Clustal W (Thompson et al. 1994) with a final optimization by eye. Homologous sequences were downloaded from GenBank (accession numbers listed in Supplementary Material, Table S2) to test the consistency of the groups obtained in this study at species level. Additionally, sequences from GenBank for species that belong to the same genera, from regions other than the Mediterranean were downloaded when available (Supplementary Material, Table S2).

Evolutionary analyses of the CO1 haplotypes were performed using the maximum likelihood (ML) procedure run on Mega 6.0 (Tamura et al. 2013). Alternatively, the Bayesian inference (BI) was performed using MrBayes 3.1 (Ronquist and Huelsenbeck 2003). The most appropriate model of molecular evolution was identified using Mega 6.0. The ML analysis was conducted using the $\mathrm{HKY}+\mathrm{G}+\mathrm{Y}$ model, which was selected for its lowest BIC score, using a discrete gamma distribution $(\mathrm{G}=0.95)$, with five rate categories and a number of invariant sites estimated from the data $(\mathrm{I}=0.49)$. Evaluation of the statistical confidence in the tree nodes was based on 10000 non-parametric bootstrap replicates. For the Bayesian analysis, the general time reversible substitution model was implemented with a gamma-distributed rate variation across sites, and across a proportion of invariable sites. The standard deviation of the split frequencies fell to 0.14 after 500000 generations. With the mtDNA $12 \mathrm{~S}$ rRNA marker, the $\mathrm{K} 2 \mathrm{P} \mathrm{G}+\mathrm{I}$ model was the best to fit ML analysis and BI (mean split frequency $=0.0089$; ngen $=1000000$ ).

The evolutionary interpretation was cautiously restricted to the most external branches due to the problems arising from using one gene. The species Bathylagus euryops (Goode and Bean, 1896) was chosen as the outgroup taxon of early teleost to root both evolutionary trees.

\section{RESULTS}

All of the individuals that were used in the genetic analysis were previously identified on the basis of morphological and pigmentation patterns (Supplementary Material, Table S3). Adults were characterized by complete squamation over the body and complete photophore and osteological development. The larval specimens selected for the study ranged in size from 4.1-13.9 $\mathrm{mm}$ standard length, and had completely different body shapes to the adults, with no photophore or osteological development.

A summary of the specimens analysed, body size range, stage of development, the genetic marker employed and number of sequenced individuals is dis- 
played in Table 1. New sequences were submitted to the GenBank database. Moreover, this study contributed to the GenBank database with unique CO1 and mtDNA $12 \mathrm{~S}$ rRNA sequences of the exclusive Mediterranean $N$. elongatus and C. pygmaea, and more widely distributed fishes Lampanyctus crocodilus (Risso, 1810), Lampanyctus pusillus (Johnson, 1890), Lobianchia dofleini (Zugmayer, 1911), Diaphus holti Tåning, 1918 and $V$. attenuata. Their accession numbers along with the number of nucleotides of each sequence are listed in Supplementary Material, Table S2.

\section{Analyses using CO1}

At least 565 nucleotides of the mtDNA CO1 region were sequenced in 41 adult specimens (Supplementary Material, Table S2). For most species, at least 2 representative adults and 2 larvae were analysed. However, the stomiiform A. hemigymnus was represented by only one adult because of technical problems during PCR amplification. The sample collection had only one adult specimen of Notoscopelus bolini Nafpaktitis, 1975, N. elongatus and Electrona risso (Cocco, 1829). A single sequence of an adult of Symbolophorus veranyi (Moreau, 1888) (SvA3) was amplified using the different sets of primers, after re-sequencing several fragments from the larval and adult specimens without success. Some sequences from the larvae and adults, not reported here, were deleted from the alignment after an extensive span of ambiguous nucleotides.

A selection of 25 larval individuals (listed in Table 1) was amplified using FishF1/R1 and LCO1Myc1/ LCO1Myc2, and sequencing was achieved for 22 of them. Three larvae of $S$. veranyi were the only myctophid specimens for which sequencing was not effective using the reported primers. No stop codons, insertions or deletions were found in any of the amplified sequences, indicating that these sequences constituted functional mitochondrial CO1 sequences. Negligible genetic variability was due to PCR errors $\left(3.4 \times 10^{-5}\right)$.

Sequence comparisons among the 70 adult sequences in Supplementary Material, Table S2, identified 331 conserved sites and 239 variable sites, with an overall mean distance of $0.201(\mathrm{SD}=0.024)$. Of these sites, 235 were phylogenetically informative. Of the $570 \mathrm{bp}$ of unambiguously aligned sequences within the myctophids (51 sequences), 347 were conserved sites $(60.9 \%)$, and 223 were variable sites (nucleotide diversity, $\varpi=0.189$ ). The sequences of the stomiiforms $(n=19)$ contained 197 variable sites $(\varpi=0.164)$, so 373 $(65.4 \%)$ of the sites were invariant. The overall nucleotide frequencies were T $(28 \%), \mathrm{C}(31.6 \%), \mathrm{A}(22.8 \%)$ and $\mathrm{G}(17.6 \%)$.

The mean sequence distances between the Mediterranean species was nearly 10-fold higher than the within-species mean distances. Estimates of net evolutionary divergence between species groups of sequences are presented in Supplementary Material, Table S4. The maximum average divergence within species over sequence pairs was for $D$. holti (Table $2 \mathrm{~A}$ ). The maximum interspecific difference (number of base substitutions per site based on the estimation of the net average
Table 2. - Within-species (A) and within-genus (B) genetic distances among Mediterranean individuals (larvae and adults). Number of base substitutions per site from averaging the overall sequence pairs within each group is shown in the second column along with the corresponding standard error (SE) estimates. Analyses were conducted using the maximum composite likelihood model and the rate of variation among sites was modeled using gamma distribution (shape parameter $=5$ ). The included codon positions were $1 \mathrm{st}+2 \mathrm{nd}+3 \mathrm{rd}+$ Non-coding. All ambiguous positions were removed for each sequence pair.

\begin{tabular}{lcc}
\hline A. Species & Distance & S. E. \\
\hline Benthosema glaciale & 0.0077 & 0.0024 \\
Ceratoscopelus maderensis & 0.0135 & 0.0031 \\
Diaphus holti & 0.0212 & 0.0042 \\
Hygophum benoiti & 0.0032 & 0.0014 \\
Hygophum hygomii & 0.0077 & 0.0030 \\
Lampanyctus crocodilus & 0.0059 & 0.0025 \\
Lobianchia dofleini & 0.0170 & 0.0029 \\
Lampanyctus pusillus & 0.0028 & 0.0014 \\
Maurolicus muelleri & 0.0028 & 0.0014 \\
Myctophum punctatum & 0.0040 & 0.0015 \\
Vinciguerria attenuata & 0.0005 & 0.0005 \\
\hline B. Genus & & \\
\hline Hygophum & 0.0741 & 0.0092 \\
Lampanyctus & 0.1003 & 0.0101 \\
Diaphus & 0.1077 & 0.0100 \\
Notoscopelus & 0.0538 & 0.0072 \\
Vinciguerria & 0.1146 & 0.0101 \\
\hline
\end{tabular}

between species groups) was between $V$. attenuata and L. pusillus $(29.7 \%)$, and the minimum distance was between $N$. elongatus and $N$. bolini $(6.2 \%)$.

The overall mean distance computed when the 25 larval sequences were incorporated increased to 0.22 $(\mathrm{SD}=0.0136)$. The intraspecific variation ranged from $0.05 \%$ to $2.12 \%$ for the Mediterranean species.

ML and BI methods were employed to yield two alternative phylogenetic trees (Figs. 1 and 2, respectively), with $B$. euryops as the outgroup taxon (Protacanthopterygii), as well as the sister group of the $\mathrm{Ne}$ oteleostei, which includes the orders Myctophiformes and Stomiiformes. The tree topology was congruent between phylogenetic methods except for some intermediate nodes, although there was consensus for the congeneric clades and most tribes. A monophyletic group was considered significant when the bootstrap value for that clade reached $95 \%$ and was defined by more than two exemplars from the same species. Accordingly, the orders Myctophiformes and Stomiiformes are consistently monophyletic in both phylogenies (ML and $\mathrm{BI}$ ).

Several features were conserved in both trees. Within Lampanyctinae Lampanyctus spp. and Ceratoscopelus maderensis (Lowe, 1839) were sister groups and within Diaphini L. dofleini and D. holti were clustered together. GenBank sequences of Diaphus spp. were also clustered with our sequences of $D$. holti (ML: $70 \%$ bootstrapping; BI: $100 \%$ posterior probability), which constituted a different unit that diverged from other individuals of the same genus. The tribe Diaphini (L. dofleini + Diaphus spp.) was only recovered via ML. The Notoscopelus spp. appeared mixed with the Myctophinae species via ML, but placed within the Lampanyctinae using BI, which was in agreement with the morphological classification. Within Myctophinae, S. veranyi and Myctophum punctatum Rafinesque 1810 


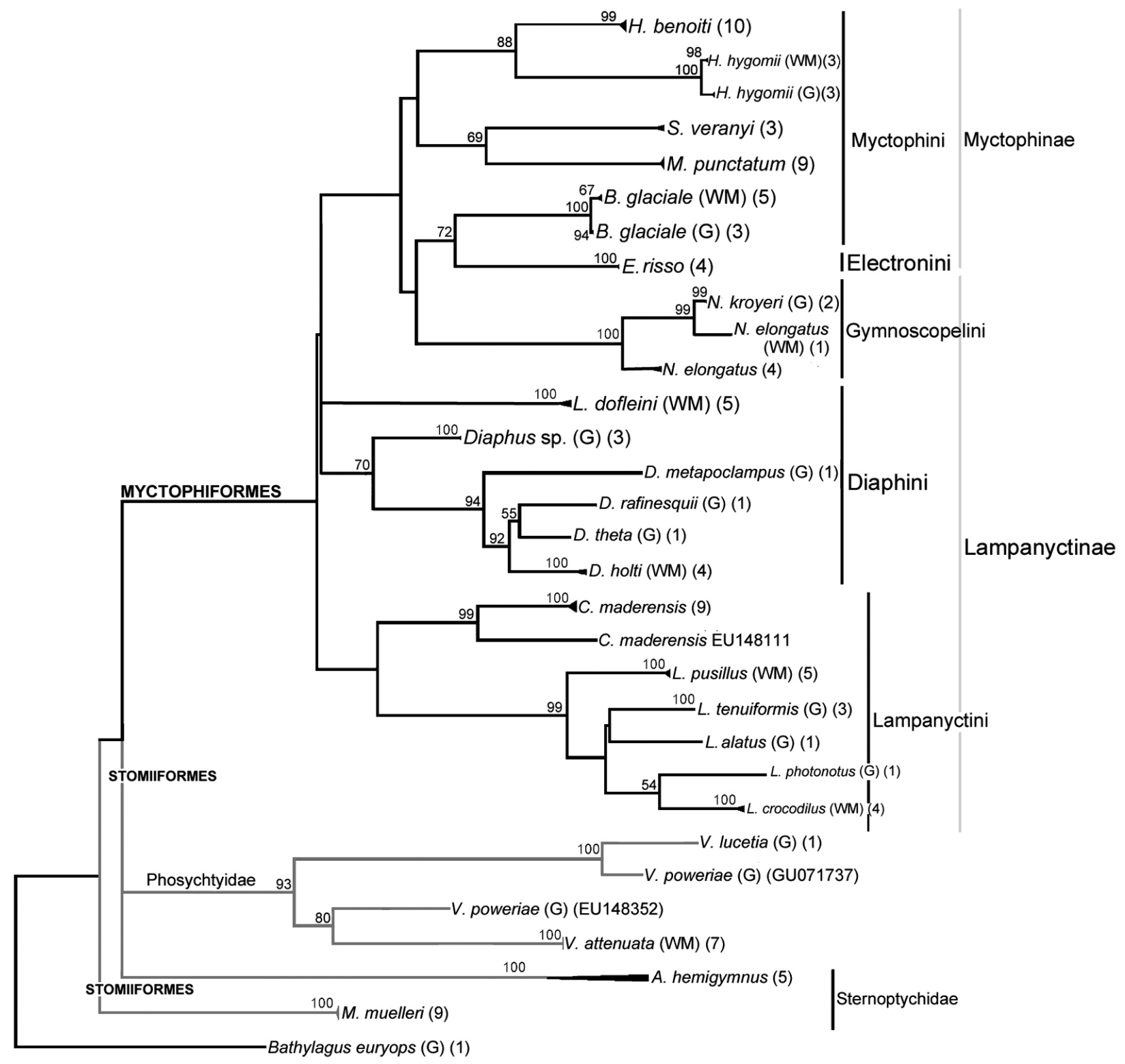

Fig. 1. - Maximum likelihood tree using CO1 sequences of different stages of species of Myctophiformes and Stomiiformes. Species were sequenced and downloaded from GenBank and inferred using the method based on the Hasegawa-Kishino-Yano model with the highest log likelihood (-6992.6923). A discrete gamma distribution was used to model evolutionary rate differences among sites (5 categories; $+\mathrm{G}$, parameter $=0.9685)$. The rate variation model allowed for some sites to be evolutionarily invariable (+I, $49.5529 \%$ sites). The analysis involved 111 nucleotide sequences. Clades represented by various individuals of the same species were contracted. Branches with the (WM) nomenclature correspond solely to sequences from the western Mediterranean (this study) and those with the (G) nomenclature were from GenBank. The rest of the branches depict a mixture of this study and GenBank sequences. Numbers in brackets represent the number of sequences for a clade. Bootstrap values are shown as percentages above the branches, and values below 50 were not included.

formed a sister group with a support of $69 \%$ bootstrapping and 0.99 posterior probability using $\mathrm{ML}$ and $\mathrm{BI}$, respectively.

The congeners Hygophum benoiti (Cocco, 1838) and Hygophum hygomii (Lütken, 1892) were clustered with bootstrap values over $80 \%$; L. pusillus and $L$. crocodilus had values over $99 \%$; and N. bolini and $N$. elongatus also had $99 \%$, which underlies the monophyly of these genera. These nodes had $100 \%$ values using BI. The clades produced within the species accounted for values of $99 \%-100 \%$ bootstrapping and
$100 \%$ probability for the respective procedures. Some discrepancies between the two evolutionary trees for the deeper nodes were evident and remained consistent at the genus and species levels.

In accordance with the main objective of this study, it can be demonstrated from both genealogies that the larvae identified using detailed morphological features corresponded with the adult specimens in the 11 species for which larvae were successfully sequenced. All specimens were clearly assigned to each species at $100 \%$ bootstrapping and posterior probability values. 


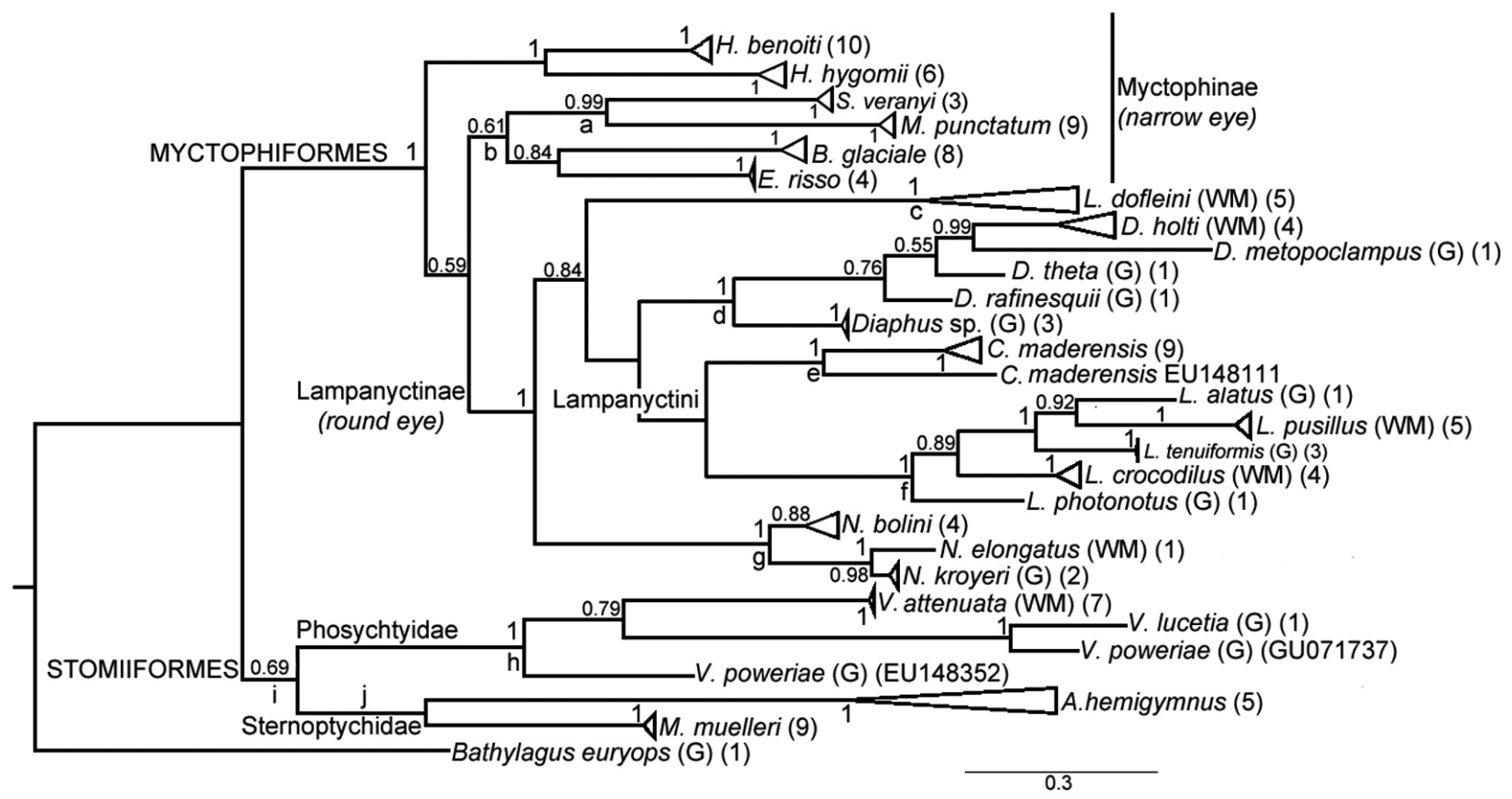

Fig. 2. - Bayesian tree (split frequency=0.14; 500000 generations) involving the same 111 nucleotide sequences of larvae and adults as in the ML cladogram. Clades represented by various individuals of the same species were contracted. Branches with the (WM) nomenclature correspond solely to sequences from the western Mediterranean (this study) and those with the $(\mathrm{G})$ nomenclature were from GenBank. The rest of branches depict a mixture of this study and GenBank sequences. Numbers in brackets represent the number of sequences for a clade. Letters in lower case close to some nodes present main morphological characters of larvae: a, pectoral fin moderately large and stalked eyes; b, slender body and gut length up to the mid-point of the body; c, conspicuous and very large pectoral fin; $\mathrm{d}$, early photophore development; $\mathrm{e}$, slender and slightly sigmoid gut; f, body moderately deep and S-shaped gut; g, pigment above brain and gas bladder; h, gut length ca. $75 \%$ of the body length; i, slender body and scant / lacking pigment; j, no pigmentation. Values of posterior probability are shown besides the nodes. The branches depict the proportional mean evolutionary distances among clades.

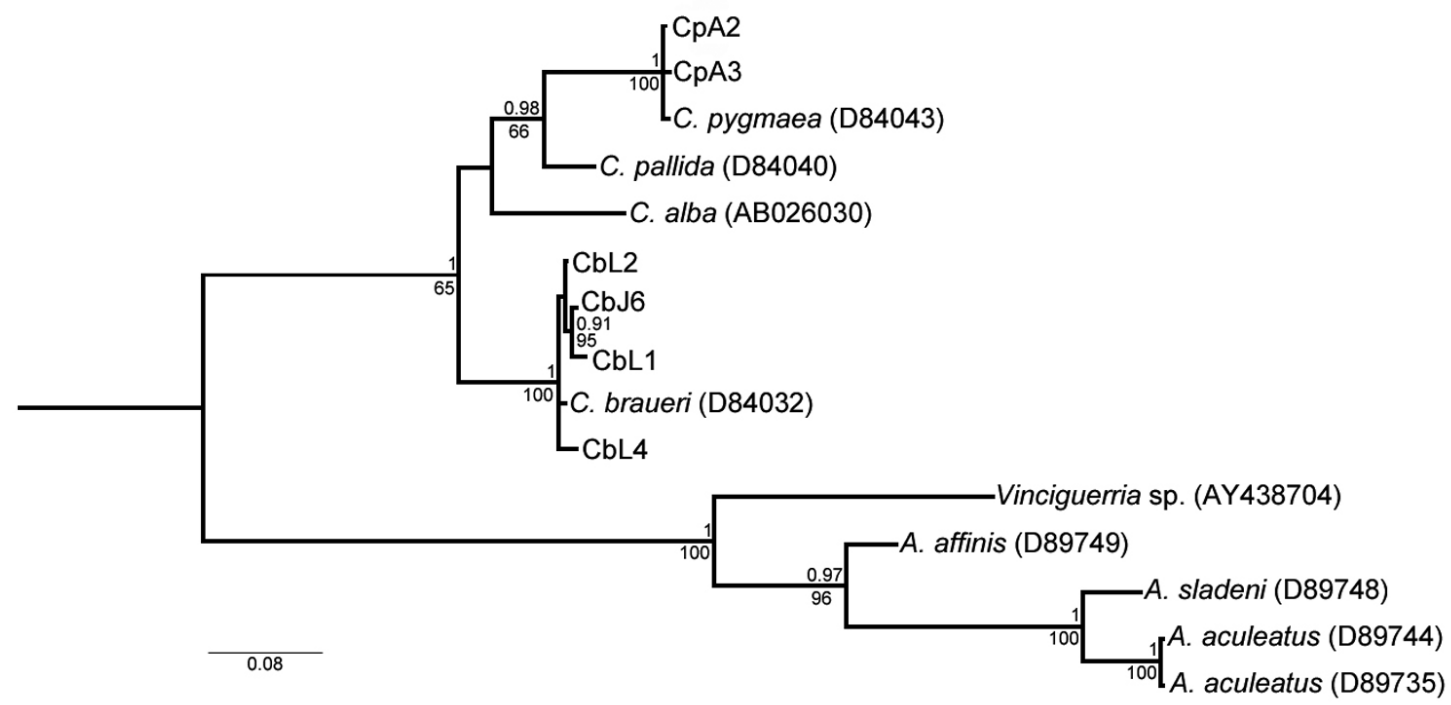

Fig. 3. - Bayesian tree (in consensus with the ML and MP procedures) based on an alignment of 417 bp of 12S-rRNA mtDNA sequences. The branches depict the proportional mean evolutionary distances among clades. The posterior probability values of each node $>0.9$ are depicted above the branches, and the bootstrap values below the branches.

Therefore, the adult associations were well structured and could be used as a basis for FINS of the larvae, followed by phylogenetic reconstruction.

\section{Analyses using the mtDNA 12S rRNA}

In the present work, all the species were sequenced with $\mathrm{CO} 1$, although some stomiiforms (Cyclothone spp.) did not render proper chromatograms. In these instances, the mtDNA $12 \mathrm{~S}$ rRNA region was used. However, the disparity is unclear, as specimens were collected and stored in the same conditions as the rest of samples.

The validity of the mtDNA $12 \mathrm{~S}$ rRNA sequences was briefly analysed by depicting a tree of the C. braueri and C. pygmaea sequences from the Mediterranean 
in combination with GenBank sequences of other $C y$ clothone spp. and stomiiforms. The consensus trees obtained from BI and ML produced identical groupings (Fig. 3).

Six fragments of 375 nucleotides from three larvae and one adult $C$. braueri, and 2 adults of $C$. pygmaea were sequenced. Fifty-seven variable sites involving the 6 nucleotide sequences with low diversity $(\varpi=9.17$ $10^{-2}$ ) were found. The 2 species of Cyclothone were strongly discriminated with bootstrap values of $100 \%$ and $100 \%$ posterior probability.

The species of Vinciguerria formed an assembly with $85 \%$ bootstrapping ( $V$. attenuata was grouped with a value of 99\%) and was joined to the sternoptychid species with a support of $61 \%$ by BI. The species A. hemigymnus and M. muelleri were clustered with values of $99 \%$ and $100 \%$ via ML and BI, respectively. Both species formed the sternoptychid cluster with a value of $99 \%$ probability using BI.

\section{DISCUSSION}

Due to its rapid evolutionary rate, mtDNA has been used to discern between adults of closely related species, and is becoming a common tool for the identification of early developmental stages of fishes (e.g. Hare et al. 1994, Pegg et al. 2006, Ko et al. 2013). The consistent genetic profiles between larvae and adults of all the analysed mesopelagic fishes have proved the usefulness of this methodology for larval identification, and the accuracy of previous larval descriptions based on morphology and pigmentation patterns. The low species richness of mesopelagic fishes in the western Mediterranean, with just one or two species per genus, makes it a good scenario for unequivocal identification when it comes to elusive characters such as those of larval stages.

The divergence values between nucleotide sequences give a perspective of the specific diversity of the sampling region (Steinke et al. 2009). High sequence divergence between species compared with intraspecific variation indicates good barcode matching. For instance, the difficulties arising in the morphological identification of congeners within Cyclothone, Hygophum, Lampanyctus and Notoscopelus were solved through barcoding. The availability of large datasets of nucleotide sequences would be useful to design primers for particular species in cases in which morphological determination is difficult (Ko et al. 2013, Webb et al. 2006). As a result, the hybridization of unknown nucleotide sequences of mtDNA with fragments designed specifically makes an accurate species determination possible.

The significance of this study lies in the lack of previous larval identification by genetic methods to corroborate morphological classifications. Additionally, the study aimed to highlight the need for morphological identification in combination with DNA barcoding to detect the biodiversity of a region. As Barber and Boyce (2006) suggested, the synergy between taxonomists and geneticists advances our understanding of groups with high intraspecific genetic variation that could actually represent cryptic species.
Genetic analysis based on mtDNA has been useful in establishing phylogenetic relationships among mesopelagic and other deep-sea fishes (Miya and Nishida 1998, Miya et al. 2001, Poulsen et al. 2013). The results presented here identified two wide clusters corresponding to the recognized monophyletic orders Myctophiformes and Stomiiformes (e.g. Paxton 1972, Fink 1984, Poulsen et al. 2013) using ML and BI methods (Fig. 1 and Fig. 2). The Bayesian tree was also able to recover the families Myctophidae, Phosyctidae and Sternoptychidae, and the subfamily Lampanyctinae. However, the phylogenetic branches defined by morphological characteristics (Paxton 1972, Paxton et al. 1984) could only be identified in this study at a lower taxonomic level than tribe with well-structured congeneric groups. It is recognized that the use of concatenated, protein-coding genes or complementary mitochondrial regions is necessary to significantly categorize the higher ranks of taxonomy. It should be noted that redefining the precise phylogenetic relationships of myctophiforms and stomiiforms was outside the main objective of the present study. However, some of the associations found within the subfamilies and sister groups deserve some comment.

The subfamily Lampanyctinae was represented by Lampanyctus spp. and C. maderensis within the tribe Lampanyctini and L. dofleini and Diaphus spp. within the tribe Diaphini, in agreement with the morphological classification by Paxton (1972) and Paxton et al. (1984). Paxton (op. cit.) stated lower divergence between Lobianchia and Diaphus than between Lampanyctus and Ceratoscopelus. The two former genera constituted a sister group that was characterized by the exclusive apomorphic state of having a wide pubic plate. However, the evolutionary distance within Diaphini (0.186; Supplementary Material, Table S4) was slightly lower than that within Lampanyctini (0.189).

Diaphus and Lampanyctus are greatly diversified genera with low morphological variation (Hulley 1981). The observed average within-genus nucleotide diversity of Diaphus (4 species) and Lampanyctus (5 species) (10.7 and $10 \%$, respectively) was nearly two times greater than that within Notoscopelus (3 species) $(5.3 \%)$. Thus, it might reflect a more recent divergence of the genus Notoscopelus. This genus is represented in the Mediterranean by two species: $N$. elongatus, which is restricted to the Mediterranean Sea, and its congener N. bolini, which has also been captured in the Atlantic Ocean. N. elongatus and N. bolini showed the minimum interspecific genetic distance between the Mediterranean species $(6.22 \%)$, similar to other values reported for congeneric species in previous analyses of marine fishes (Ward et al. 2005, Steinke et al. 2009). Both congeners constitute separate species in the Mediterranean that are barely distinguished by the number of gill rakers and fin ray counts in adults (Hulley 1984), and pigmentation features in larvae (Palomera 1983). The low degree of morphological divergence was consistent with this study, suggesting a relatively recent separation of this genus in the Mediterranean. On the other hand, relatively high intraspecific divergence 
(2.1\%) was found in $D$. holti, which could be masking cryptic species or reflecting an underlying population structure. Ideally, this could be overcome by an extensive within-species variation that embraces all of the species diversity (Viñas and Tudela 2009).

In the subfamily Myctophinae, the sister groups $M$. punctatum and $S$. veranyi and $H$. hygomii and $H$. benoiti coincided with the morphological phylogeny (Paxton 1972, Paxton et al. 1984). M. punctatum and S. veranyi (tribe Myctophini) shared a slender larval morphotype, with a fan-shaped pectoral fin base and slightly stalked eyes (Supplementary Material, Table S3). Our molecular data produced high significance values (BI) to support the monophyly of Hygophum. The two species of Hygophum of the Mediterranean region were consistent with the morphological classification and with the genetic results reported by Yamaguchi et al. (2000).

Genetic divergence of the Mediterranean specimens from those of GenBank, which represent remote populations in some cases Atlantic or Pacific populations, revealed that some genera showed larger divergence than others. For instance, the intraspecific distance in Benthosema glaciale (Reinhardt, 1837) and N. elongatus from the Mediterranean sensu stricto was smaller than that including individuals from other regions (i.e. GenBank sequences), a finding which coincides with the assumption of different populations in the Mediterranean and North Atlantic.

Analysis of mtDNA $12 \mathrm{~S}$ rRNA sequences for the Mediterranean Cyclothone, along with other GenBank sequences of stomiiforms, produced clusters (BI, ML) in agreement with the cladograms of Weitzman (1974) and Fink (1984) using morphological characters. The species of the family Sternoptychidae and Phosichthyidae appeared closer than to the gonostomatid $C y$ clothone spp. The sternoptychids $M$. muelleri and $A$. hemigymnus were also clustered together using CO1 sequences.

The genus Maurolicus deserves special mention as it has been challenging in terms of species identification. Whether it is composed of a single species, M. muelleri, with wide distribution in the Atlantic, Indian and Pacific Oceans, or includes up to 15 species, as stated by Parin and Kobyliansky (1996), remains unclear. Mediterranean specimens of $M$. muelleri showed similar haplotypes with low genetic variation and were grouped with GenBank sequences from Atlantic specimens, revealing that they originated from the same species.

In summary, the results of the present study highlighted the validity of DNA barcoding to differentiate the Mediterranean mesopelagic fish at the species level, even among those with high morphological resemblance. The good fit of genetic sequences between larvae and adults of each species proved the accuracy of earlier larval descriptions based on morphology and pigmentation characters. Phylogenetic relationships of myctophiforms and stomiiforms still require additional sequencing of mitochondrial or nuclear loci to be further resolved. Although the use of long CO1 sequences allowed a similar grouping of some tribes accepted in the current phylogeny.

\section{ACKNOWLEDGEMENTS}

We thank all the colleagues who participated in the IDEADOS cruise for their help in collecting the samples, and the crew of the Research Vessel Sarmiento de Gamboa for their assistance during the survey. The authors are also grateful to Luis Peñarrubia for his assistance in the DNA analyses and to the Biology Department of the Universitat de Girona. American Journal Experts edited the English version. This work was supported by Spanish projects CTM200804489-C03-02 and CTM2012-39587-C04-03, and it constitutes a section of the $\mathrm{PhD}$ thesis of $\mathrm{A}$. Bernal. A. Bernal acknowledges the predoctoral FPI Fellowship support from Spain's Ministry of Economy and Competitiveness.

\section{REFERENCES}

Ahlstrom E.H. 1974. The diverse patterns of metamorphosis in gonostomatid fishes - An aid to classification. In: Blaxter J.H.S (ed), The early life history of fish. Berlin: Springer-Verlag, pp. 659-674. http//dx doi org/10.1007/978-3-642-65852-5 52

Badcock J. 1984. Gonostomatidae, Sternoptychidae, Photichthyidae. In: Whitehead P.J.P., Bauchot M.L., Hureau J.C., Nielsen J., Tortonese E. (eds), Fishes of the north-eastern Atlantic and the Mediterranean, vol. 1. Paris: UNESCO, pp. 284-324.

Barber P., Boyce S.L. 2006. Estimating diversity of Indo-Pacific coral reef stomatopods through DNA barcoding of stomatopod larvae. Proc. R. Soc. Lond., B. 273: 2053-2061. http://dx.doi.org/10.1098/rspb.2006.3540

Bartlett S.E., Davidson W.S. 1992. FINS (forensically informative nucleotide sequencing): a procedure for identifying the animal origin of biological specimens. Biotechniques 12: 408-411.

Berdar A., Cavaliere A. 1975. Stadi larvali e postlarvali di mictofidi: Lobianchia dofleini. Atti Soc. Pelorit. Sci. Fis. Mat. Nat. 21: 115-122.

Blaxter J.H.S. 1984. Ontogeny, systematics and fisheries. In: Moser H.G., Richards W.J., Cohen D.M., Fahay M.P., Kendall A.W., Richardson S.L. (eds), Ontogeny and systematics of fishes, Spec. Publ. 1. Lawrence, KS: Am. Soc. Ichthyol. Herpetol., pp. 1-6.

Burton R.S. 1996. Molecular tools in Marine Ecology. J. Exp. Mar. Biol. Ecol. 200: 85-101. http://dx.doi.org/10.1016/S0022-0981(96)02641-X

Cocco A. 1829. Su du alcuni nuovi pesci de' mari di Messina. Giornale di Scienze, Lettere e Arti per La Sicilia, Anno 7 26(77): $138-147$

Cocco A. 1838. Observazioni intorno taluni pesci del mare di Messina, Lettera di Anastasio Cocco al Prof. Oronzio Gabrièle Costa di Napoli. Giornale Il Faro 4.

Costa O.G. 1844. Fauna del Regno di Napoli ossia enumerazione di tutti gli animali che abitano le diverse regioni di questo Regno e le acque che le bagnano contenente la descrizione de' nuovi o poco esattamente conosciuti, con figure ricavate da originali riventi e dipinte al naturale. Dalla Stamperia di Azzolino e Compagno, Napoli.

Fink W.L. 1984. Stomiiforms: relationships. In: Moser H.G., Richards W.J., Cohen D.M., Fahay M.P., Kendall A.W., Jr. Richardson S.L. (eds), Ontogeny and Systematics of Fishes. Amer. Soc. Ichthyol. Herpetol., Spec. Publ. 1: 181-184.

Fink W.L. 1985. Phylogenetic interrelationships of the stomiid fishes (Teleostei: Stomiiformes). Misc. Publ. Mus. Zool. Univ. Mich. 171: 1-127.

Gjøsaeter J., Kawaguchi K. 1980. A review of the world resources of mesopelagic fish. FAO Fish. Tech. Pap. 193: 1-151.

Gmelin J.F. 1789. Pisces. In: Caroli a Linné, Systema Naturae per regna tria naturae secundum classes, ordines, genera, species, cum characteribus, differentiis, synonymis, locis (13th ed), 1 (3): 1126-1516.

Goode G.B., Bean T.H. 1896. Oceanic Ichthyology, a treatise on the deep-sea and pelagic fishes of the world, based chiefly upon the collections made by the steamers "Blake", "Albatross", and "Fish Hawk" in the northwestern Atlantic, with an atlas contain- 
ing 417 figures. Spec. Bull. U.S. Nat. Mus. 2: 553 p.

Goodyear R.H., Zahuranec B.J., Pugh W.L., et al. 1972. Ecology and vertical distribution of Mediterranean midwater fishes. In: Mediterranean Biological Studies (ed). Final report, vol. 1. Washington, D.C.: Smithsonian Institution, pp. 91-229.

Hall T.A. 1999. BioEdit: a user-friendly biological sequence alignment editor and analysis program for Windows 95/98/NT. Nucleic Acids Symp. Ser. 41: 95-98.

Hare J.A., Cowen R.K., Zehr J.P., et al. 1994. Biological and oceanographic insights from larval labrid (Pisces: Labridae) identification using mtDNA sequences. Mar. Biol. 118: 17-24. http://dx.doi.org/10.1007/BF00699215

Hebert P.D.N., Cywinska A., Ball S.L., et al. 2003. Biological identifications through DNA barcodes. Proc. R. Soc. Lond., B. 270: 313-322. http://dx.doi.org/10.1098/rspb.2002.2218

Hebert P.D.N., Stoeckle M.Y., Zemlak T.S., et al. 2004. Identification of birds through DNA barcodes. PLoS Biol. 2(10): 1657-1663. http://dx.doi.org/10.1371/journal.pbio.0020312

Hulley P.A. 1981. Results of the research cruises of FRV "Walther Herwig" to South America: LVIII. Family Myctophidae (Osteichthyes, Myctophiformes). Archiv. FischWiss. 31: 1-303.

Hulley P.A. 1984. Myctophidae. In: Whitehead P.J.P, Bauchot M.L. Hureau J.C. Nielsen J., Tortonese E. (eds), Fishes of the North-eastern Atlantic and the Mediterranean, vol. 1. Paris: UNESCO, pp. 429-483.

Jespersen P., Tåning A.V. 1926. Mediterranean Sternoptychidae. Report on the Danish Oceanographical Expeditions 1908-1910 2: 59.

Johnson J.Y. 1890. On some new species of fishes from Madeira. Proc. Zool. Soc. Lond. 1890: 452-459.

Johnson G.D., Paxton J.R., Sutton T.T, et al. 2009. Deep-sea mystery solved: astonishing larval transformations and extreme sexual dimorphism unite three fish families. Biol. Lett. 5: 235-239. http://dx.doi.org/10.1098/rsbl.2008.0722

Ko H-L, Wang Y-T, Chiu T-S, et al. 2013. Evaluating the accuracy of morphological identification of larval fishes by applying DNA barcoding. Plos One 8: e53451. http://dx.doi.org/10.1371/journal.pone.0053451

Kochzius M., Seidel C., Antoniou A., et al. 2010. Identifying fishes through DNA barcodes and microarrays. PLoS One 5: e12620. http://dx.doi.org/10.1371/journal.pone.0012620

Lowe R.T. 1839. A supplement to a synopsis of the fishes of Madeira. Trans. Zool. Soc. Lond. 3: 1-20.

Lütken C.F. 1892. Nogle nordiske Laxesild (Scopeliner). Korte bidrag til Nordisk ichthyographi, VIII. Vidensk. Medd. Dan. Naturhist. Foren. 43: 203-233.

Miya M., Nishida M. 1998. Molecular phylogeny and evolution of the deep-sea fish genus Sternoptyx. Mol. Phylogenet. Evol. 10: $11-22$. http://dx.doi.org/10.1006/mpev.1997.0479

Miya M., Nishida M. 2000. Use of mitogenomic information in teleostean molecular phylogenetics: A tree-based exploration under the maximum-parsimony optimality criterion. Mol. Phylogenet. Evol. 17: 437-455. http://dx.doi.org/10.1006/mpev.2000.0839

Miya M., Kawaguchi A., Nishida M. 2001. Mitogenomic exploration of higher teleostean phylogenies: a case study for moderate-scale evolutionary genomics with 38 newly determined complete mitochondrial DNA sequences. Mol. Biol. Evol. 18: 1993-2009. http://dx.doi.org/10.1093/oxfordjournals.molbev.a003741

Moreau E. 1888. Le scopele de Verany, Scopelus veranyi. Bull. Soc. Philomath. Paris (Ser. 7), 12 (3): 108-111.

Moore W.S. 1995. Inferring phylogenies from mtDNA variation: mitochondrial-gene trees versus nuclear-gene trees. Evolution 49: 718-726. http://dx.doi.org/10.2307/2410325

Moser H.G., Ahlstrom E.H. 1974. The role of larval stages in systematic investigations of marine teleosts: The Myctophidae, a case study. In: Blaxter J.H.S (ed), The early life history of fish. Berlin: Springer-Verlag, pp.605-607. http://dx.doi.org/10.1007/978-3-642-65852-5 48

Moser H.G., Ahlstrom E.H., Paxton J.R. 1984. Myctophidae: Development. In: Moser H.G., Richards W.J., Cohen D.M., et al. (eds), Ontogeny and systematics of fishes, Spec. Publ. 1. Lawrence, KS: Am. Soc. Ichthyol. Herpetol., pp. 218-239.

Moura T., Silva M.C., Figueiredo I., et al. 2008. Molecular barcoding of north-east Atlantic deep-water sharks: species identifica- tion and application to fisheries management and conservation. Mar. Freshw. Res. 59: 214-223 http://dx.doi.org/10.1071/MF07192

Nafpaktitis B.G. 1975. Review of the lanternfish genus Notoscopelus (family Myctophidae) in the North Atlantic and the Mediterranean. Bull. Mar. Sci. 25 (1): 75-87.

Nafpaktitis B.G., Backus R.H., Craddock J.E., et al. 1977. Family Myctophidae. In: Mem. Sears Found. Mar. Res (ed), Fishes of the western North Atlantic. New Haven: Yale University 1, pp. 13-265

Olivar M.P., Beckley L.E., Moser H.G. 1999. Lanternfish larvae from the Agulhas Current (Sw Indian Ocean). Sci. Mar. 63: 101-120.

Olivar M.P., Bernal A., Molí B., et al. 2012. Vertical distribution, diversity and assemblages of mesopelagic fishes in the western mediterranean. Deep-Sea Res. Part I. 62 (0): 53-69. http://dx.doi.org/10.1016/j.dsr.2011.12.014

Palomera I. 1983. Desarrollo larvario de Notoscopelus elongatus elongatus (Costa, 1844) y Notoscopelus bolini Nafpaktitis, 1975. Invest. Pesq. (Spain) 47 (2): 263-276.

Parin N.V., Kobyliansky S.G. 1996. Diagnoses and distribution of fifteen species recognized in genus Maurolicus Cocco (Sternoptychidae, Stomiiformes) with a key to their identification. Cybium 20(2): 185-195.

Paxton J.R. 1972. Osteology and relationships of the lanternfishes (Family Myctophidae). Sci. Bull. 13: 1-81.

Paxton J.R., Ahlstrom E.H., Moser H.G. 1984. Myctophidae: Relationships. In: Moser H.G., Richards W.J., Cohen D.M., et al. (eds), Ontogeny and systematics of fishes. Lawrence, KS: Am. Soc. Ichthyol. Herpetol. Spec. Publ. 1: 239-244.

Pegg G.G., Sinclair B., Briskey L., et al. 2006. MtDNA barcode identification of fish larvae in the southern Great Barrier Reef, Australia. Sci. Mar. 70S2: 7-12.

Poulsen J., Byrkjedal I., Willassen E.,et al. 2013. Mitogenomic sequences and evidence from unique gene rearrangements corroborate evolutionary relationships of myctophiformes $(\mathrm{Ne}-$ oteleostei). BMC Evol. Biol. 13 (1): 1-22. http://dx.doi.org/10.1186/1471-2148-13-111

Rafinesque C.S. 1810. Indice d'Ittiologia Siciliana. Messina. 70 p.

Reinhardt J.C.H. 1837. Ichthyologiske bidrag til den grönlandske fauna. København. Col. Pl. I-VIII: 1-114.

Richards W.J. 2006. Order stomiiformes. In: Richards W.J. (ed), Early stages of Atlantic fishes: An identification guide for the western Central North Atlantic. CRC Mar. Biol. Ser. 1: 177-182.

Risso A. 1810. Ichthyologie de Nice, ou histoire naturelle des poissons du départament des Alpes Maritimes. Tome 26. Paris. 388 pp.

Ronquist F., Huelsenbeck J.P. 2003. MrBayes 3: Bayesian phylogenetic inference under mixed models. Bioinformatics 19: 1572-1574. http://dx.doi.org/10.1093/bioinformatics/btg180

Rozen S., Skaletsky H.J. 2000. Primer 3 on the WWW for general users and for biologist programmers. Bioinformatics methods and protocols: methods in Molecular Biology. Krawetz S.M.S. Totowa N.J. (eds). Humana Press: 365-386.

Sanzo L. 1931. Stomiatoidei, Sternoptichidae. Uova, larve e stadi giovanili di teleostei. Fauna e Flora Golfo di Napoli. 38: 42-92.

Steinke D., Zemlak T., Boutillier J.A., et al. 2009. DNA barcoding of Pacific Canada's fishes. Mar. Biol. 156 (12): 2641-2647. http://dx.doi.org/10.1007/s00227-009-1284-0

Takeyama H., Chow S., Tsuzuki H., et al. 2001. Mitochondrial DNA sequence variation within and between tuna Thunnus species and its application to species identification. J. Fish Biol. 58 (6): 1646-1657. http://dx.doi.org/10.1111/j.1095-8649.2001.tb02319.x

Tamura K., Stecher G., Peterson D., et al. 2013. Mega 6: Molecular Evolutionary Genetics Analysis Version 6.0, Mol. Biol. Evol. 30: $1725-2729$ http://dx.doi.org/10.1093/molbev/mst197

Tåning Å.V. 1918. Mediterranean Scopelidae: (Saurus, Aulopus, Chlorophthalmus and Myctophum). Rep. Dan. Oceanogr. Exped. 1908-1910. 2: 1-154.

Thompson J.D., Higgins D.G., Gibson T.J. 1994. Clustal W: Improving the sensitivity of progressive multiple sequence alignment through sequence weighting, position-specific gap penalties and weight matrix choice. Nucleic Acids Res. 22 (22): 4673-4680. http//dx doi.org/10.1093/nar/22.22.4673

Valdez-Moreno M., Vásquez-Yeomans L., Elías-Gutiérrez M., et al. 2010. Using DNA barcodes to connect adults and early life stages of marine fishes from the Yucatan Peninsula, Mexico: 
Potential in fisheries management. Mar. Freshw. Res. 61 (6): 655-671.

http://dx.doi.org/10.1071/MF09222

Viñas J., Tudela S. 2009. A validated methodology for genetic identification of tuna species (genus Thunnus). PLoS One 4: e7606. http://dx.doi.org/10.1371/journal.pone.0007606

Ward R.D., Zemlak T.S., Innes B.H., et al. 2005. DNA barcoding Australia's fish species. Philos. Trans. R. Soc. Lond. B. 360 (1462): 1847-1857. http://dx.doi.org/10.1098/rstb.2005.1716

Webb K.E., Barnes D.K.A., Clark M.S., et al. 2006. DNA barcoding: a molecular tool to identify Antarctic marine larvae. DeepSea Res. Part II 53: 1053-1060. http://dx.doi.org/10.1016/j.dsr2.2006.02.013

Weitzman S.H. 1974. Osteology and evolutionary relationships of the Sternoptychidae, with a new classification of stomiatoid families. Bull. Am. Mus. Nat. Hist. 153 (3): 327-478.

Yamaguchi M., Miya M., Okiyama M., et al. 2000. Molecular phylogeny and larval morphological diversity of the lanternfish genus Hygophum (Teleostei: Myctophidae). Mol. Phylogenet. Evol. 15 (1): 103-114. http://dx.doi.org/10.1006/mpev.1999.0726

Zugmayer E. 1911. Diagnoses des poissons nouveaux. Bull. Inst. Oceanogr. 193: 1-14.

\section{SUPPLEMENTARY MATERIAL}

The following material is available through the online version of this article and at the following link:

http://www.icm.csic.es/scimar/supplm/sm04072esm.pdf

Table S1. - Literature containing information on larvae and adult identification characteristics of the mesopelagic fishes analysed in this study.

Table S2. - List of sequences of myctophids and stomiiforms used in the present study. Codes for the sequences from our lab are shown on the right part of the table. Apart from our results, the sequences that were used in this study and selected from GenBank (http://www.ncbi.nlm.nih.gov/genbank) are listed with the corresponding accession number and source. The outgroup species Bathylagus euryops was included.

Table S3. - Distinctive features of larvae of the most abundant and frequent mesopelagic species occurring in the western Mediterranean. Sources of larval descriptions stated in Table S1.

Table S4. - Estimates of the net evolutionary divergence between species, considering larval and adult sequences and GenBank. The number of base substitutions per site by estimating the net average between groups of sequences is shown. Standard error estimates are shown above the diagonal. Analyses were conducted using the maximum composite likelihood model. The rate variation among sites was modeled using gamma distribution (shape parameter $=5$ ). The analysis involved 110 nucleotide sequences. The codon positions that were included were $1 \mathrm{st}+2 \mathrm{nd}+3 \mathrm{rd}+$ non-coding. All ambiguous positions were removed for each sequence pair and 570 positions were included in the final dataset. Abbreviated names: AH, Argyropelecus hemigymnus; BG, Benthosema glaciale; CM, Ceratoscopelus maderensis: DH, Diaphus holti; ER, Electrona risso; HB, Hygophum benoiti; $\mathrm{HH}$, Hygophum hygomii; LA, Lampanyctus alatus; LC, Lampanyctus crocodilus; LD, Lobianchia dofleini; LP, Lampanyctus pusillus; Lph, Lampanyctus photonotus; LT, Lampanyctus tenuiformis; MM, Maurolicus muelleri; MP, Myctophum punctatum; NB, Notoscopelus bolini; NE, Notoscopelus elongatus; SV, Symbolophorus veranyi; VA, Vinciguerria attenuata; VP, Vinciguerria poweriae. 